\title{
Denitrification in sediments as a major nitrogen sink in the Baltic Sea: an extrapolation using sediment characteristics
}

\author{
B. Deutsch ${ }^{1, *}$, S. Forster ${ }^{2}$, M. Wilhelm ${ }^{1}$, J. W. Dippner ${ }^{1}$, and M. Voss ${ }^{1}$ \\ ${ }^{1}$ Leibniz Institute for Baltic Sea Research-Warnemünde, Seestrasse 15, 18119 Rostock, Germany \\ ${ }^{2}$ University of Rostock, Albert Einstein Str. 3, 18059 Rostock, Germany \\ *now at: Department of Applied Environmental Science, Stockholm University, Sweden
}

Received: 20 March 2010 - Published in Biogeosciences Discuss.: 7 April 2010

Revised: 22 September 2010 - Accepted: 1 October 2010 - Published: 21 October 2010

\begin{abstract}
Rates of denitrification in sediments were measured with the isotope pairing technique at different sites in the southern and central Baltic Sea. The rates varied between $0.5 \mu \mathrm{mol} \mathrm{N} \mathrm{m} \mathrm{m}^{-2} \mathrm{~h}^{-1}$ in sands and $28.7 \mu \mathrm{mol} \mathrm{N} \mathrm{m}^{-2} \mathrm{~h}^{-1}$ in muddy sediments and showed a good correlation to the organic carbon contents of the surface sediments. N-removal rates via sedimentary denitrification were estimated for the entire Baltic Sea calculating sediment specific denitrification rates and interpolating them to the whole Baltic Sea area. Another approach was carried out by using the relationship between the organic carbon content and the rate of denitrification. The N-removal by denitrification in sediments varied between $426-652 \mathrm{kt} \mathrm{N} \mathrm{a}^{-1}$, which is around $48-73 \%$ of the external $\mathrm{N}$ inputs delivered via rivers, coastal point sources, and atmospheric deposition. Moreover, an expansion of the anoxic bottom areas was considered under the assumption of a rising oxycline from 100 to $80 \mathrm{~m}$ water depth. This leads to an increase of the area with anoxic conditions and an overall decrease in sedimentary denitrification by $14 \%$. Overall, we show here that this type of data extrapolation is a powerful tool to estimate the nitrogen losses for a whole coastal sea and may be applicable to other coastal regions and enclosed seas.
\end{abstract}

\section{Introduction}

Dealing with large quantities of anthropogenic nitrogen inputs is one of the biggest challenges for marine ecosystems and coastal states throughout the world. Every year up to $47.8 \times 10^{6}$ tonnes of reactive nitrogen $\left(\mathrm{N}_{\mathrm{r}}\right)$ enters the marine ecosystem via the rivers (Galloway et al., 2004) resulting in

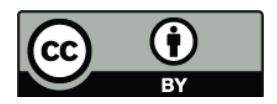

Correspondence to: B. Deutsch

(barbara.deutsch@itm.su.se) eutrophication and an expansion of dead zones in the coastal oceans e.g. Gulf of Mexico (Turner and Rabalais, 1994), the Black Sea (Mee et al., 2005; Mee, 2006), the Chesapeake Bay (Hagy et al., 2004), or the Baltic Sea (Conley et al., 2009a). A summary of sites with coastal hypoxic environments is given in Diaz and Rosenberg (2008).

Due to its specific structure with several deep basins separated by shallow sills, a shallow connection to the North Sea, and a high freshwater input, the Baltic Sea suffers from either permanent or periodic anoxia caused by water column stratification in their central parts (Schinke and Matthäus, 1998). This "natural anoxia" is enhanced by excessive nutrient inputs (Conley et al., 2009a). Changes only occur during the non-periodic salt water intrusions from the North Sea during which oxygenated high-density salt-water fills the Baltic Sea basins successively thus terminating stagnation of bottom waters (Conley et al., 2002). The depth of the oxycline is variable and during periods of stagnation located at around $100 \mathrm{~m}$ depth in the central Gotland basin (Conley et al., 2009b; Baltic Environmental Database). A rise of the oxycline to a depth of $80 \mathrm{~m}$ has been well documented in the past (Baltic Environmental Database).

During 2000-2006, an amount of $686 \mathrm{kt} \mathrm{a}^{-1} \mathrm{~N}_{\mathrm{r}}$ entered the Baltic Sea via the rivers and coastal point sources. Atmospheric deposition delivered $201 \mathrm{kt}$ (Wulff et al., 2009). Together with the $\mathrm{N}$-input via nitrogen fixation (434-792 $\mathrm{kt} \mathrm{a}^{-1}$ in the central Baltic Sea, Wasmund et al., 2001), the total annual $\mathrm{N}$ input easily exceeds $1400 \mathrm{kta}^{-1}$. Whereas riverine inputs dominate in the coastal areas, Voss et al. (2005) showed that inputs via atmospheric deposition and nitrogen fixation strongly influence the central basins. This study also stresses the possible role of coastal sediments as sites of nitrogen removal since the inputs from all sources do not show up in increasing nutrient concentrations of the central Baltic Sea. In the central part, the concentrations stayed rather constant since the 70 s (HELCOM, 1996).

Published by Copernicus Publications on behalf of the European Geosciences Union. 
Heterotrophic denitrification is one process that can permanently remove reactive nitrogen from a system. Denitrifying bacteria reduce nitrate $\left(\mathrm{NO}_{3}^{-}\right)$via nitrite $\left(\mathrm{NO}_{2}^{-}\right)$, nitric oxide (NO) and nitrous oxide $\left(\mathrm{N}_{2} \mathrm{O}\right)$ to the non-reactive dinitrogen gas $\left(\mathrm{N}_{2}\right)$ with organic carbon as electron donor (Devol, 2008). It is controlled by a variety of environmental parameters such as substrate availability, temperature, and/or oxygen concentration and the interaction between these parameters as well as the reason why one or the other parameter is dominating is under debate (Seitzinger, 1988). Another important $\mathrm{N}$ sink is the Anammox process (anaerobic ammonium oxidation) which can occur in oxygen minimum zones of the oceans (Kuypers et al., 2003, 2005; Lam et al., 2009) as well as in sediments (Dalsgaard and Thamdrup, 2002; Hietanen and Kuparinen, 2008). An increase in N-removal with nitrogen loading has been observed for different coastal ecosystems counterbalancing excessive nitrogen input (Seitzinger, 1988). Heterotrophic denitrification occurs in sediments as well as in the water column at oxygen levels below $5 \mu \mathrm{moll}^{-1}\left(\sim 0.1 \mathrm{ml} \mathrm{l}^{-1}\right)$ (Devol, 2008) and can reach rates up to $15810 \mu \mathrm{mol} \mathrm{N} \mathrm{m}{ }^{-2} \mathrm{~h}^{-1}$ in rivers (Laursen and Seitzinger, 2002). For coastal sediments, rates of up to $115 \mu \mathrm{mol} \mathrm{N} \mathrm{m}{ }^{-2} \mathrm{~h}^{-1}$ have been reported (Seitzinger et al., 1984). Estimated on a global scale, denitrification is responsible for a loss of around $40 \%$ of the total N inputs (Galloway et al., 2004) and the process is generally considered as the major process removing reactive nitrogen from the world's oceans (Hulth et al., 2005 and references therein). These losses are even higher when the whole land-sea continuum is considered (Seitzinger et al., 2006).

Little is known about the controlling factors and the general importance of sedimentary denitrification for the Baltic Sea mainly because investigations of this process are often restricted to specific sub-areas of the Baltic Sea like the Baltic Proper, Gulf of Finland, Bothnian Sea or the Bothnian Bay. However, Hietanen and Kuparinen (2008) and Tuominen et al. (1998) up-scaled their rates for the Gulf of Finland and estimated total $\mathrm{N}$-losses via denitrification and anammox of $39.1 \mathrm{kt} \mathrm{a}^{-1}$ and $45 \mathrm{kta}^{-1}$. For the Bothnian Sea and the Bothnian Bay, Stockenberg and Johnstone (1997) calculated total $\mathrm{N}$-losses via denitrification of $34.5 \mathrm{kt} \mathrm{a}^{-1}$ and $14.5 \mathrm{kta}^{-1}$, respectively. In the studies that calculated the N-losses from mass balance calculations, Shaffer and Rönner (1984) and Eilola and Stigebrandt (1999) gave Nlosses via denitrification for the Baltic Proper of $470 \mathrm{kt} \mathrm{a}^{-1}$ and $560 \mathrm{kt} \mathrm{Na}^{-1}$, respectively. Voss et al. (2005) applied a stable isotope budget approach to estimate a N-loss via denitrification from the Baltic Proper between $580-855 \mathrm{kt} \mathrm{N} \mathrm{a}^{-1}$ depending on the isotope enrichment factor they used for isotope fractionation during the denitrification process.

In this publication, we present denitrification rates determined by the isotope pairing technique for a variety of sediments from various basins and discuss the controlling environmental parameters. For the first time, a calculation of the $\mathrm{N}$-removal via sedimentary denitrification was carried out for the entire Baltic Sea by extrapolation of our measured rates. The extrapolation was based on the current knowledge of the factors governing the process, explicitly grain size and sediment organic carbon content which are both closely related. Sediment-specific denitrification rates were calculated and extrapolated using two different sediment distribution maps. Both datasets were relatively new and seemed to be the best available for the Baltic Sea region. Furthermore, the largest available set of sediment $\mathrm{C}_{\text {org }}$ data was used in another extrapolation in order to investigate the variability of the results derived from a third independent approach. Finally, we evaluated the consequences of an expansion of the anoxic bottom areas and its influence on the N-removal capacity of the sediments.

\section{Methods}

Denitrification rates from several sediment types and water depths were measured by means of the Isotope-Pairing Technique (IPT) in 2008 during several cruises and sampling (Fig. 1).

\subsection{Sampling}

Sediment samples were collected by hand (coastal sandy stations) with a Rumohr corer (Kreidesegler station) or by multi-corer and box-corer (other stations) between May and November 2008. The stations represented shallow mixed and sandy sediments (water depth $<0.3 \mathrm{~m}$ ) and deeper stations with mud, clay, mixed and sandy sediments (water depth 15$80 \mathrm{~m}$ ). Water samples for the analysis of $\mathrm{NO}_{3}^{-} / \mathrm{NO}_{2}^{-}$(Jones, 1984) and $\mathrm{O}_{2}$ concentrations (Winkler, 1888) were collected from the bottom water overlying the sediment cores and analyzed immediately or within a time frame of maximum three hours. Two extra cores per station were sliced to determine grain size distribution and the organic carbon and nitrogen contents.

\subsection{Denitrification measurements}

Sediment denitrification was measured using the isotope pairing technique (Nielsen, 1992; Risgaard-Petersen et al., 2003). Incubations were carried out in acrylic coring tubes with a height of $25 \mathrm{~cm}$ and a diameter of $3.6 \mathrm{~cm}$; half of the core filled with sediment and the remaining with bottom water. The isotope pairing experiments were performed as a concentration series to verify the assumptions underlying the method and to check for anammox activity. For this, $\mathrm{K}^{15} \mathrm{NO}_{3}^{-}$solution was added to the tubes to reach a ${ }^{15} \mathrm{NO}_{3}^{-}$ concentration of $25,50,100$ and $150 \mu \mathrm{moll}^{-1}$, respectively (three to four replicates per concentration). The cores were then equipped with stirring devices, capped and incubated in the dark at in-situ temperature for maximum $24 \mathrm{~h}$. For some sediment, the incubation time was reduced to $18 \mathrm{~h}$ (Breitling, Gollwitz 1 and 2) and $20 \mathrm{~h}$ (Arkona), respectively, to prevent 


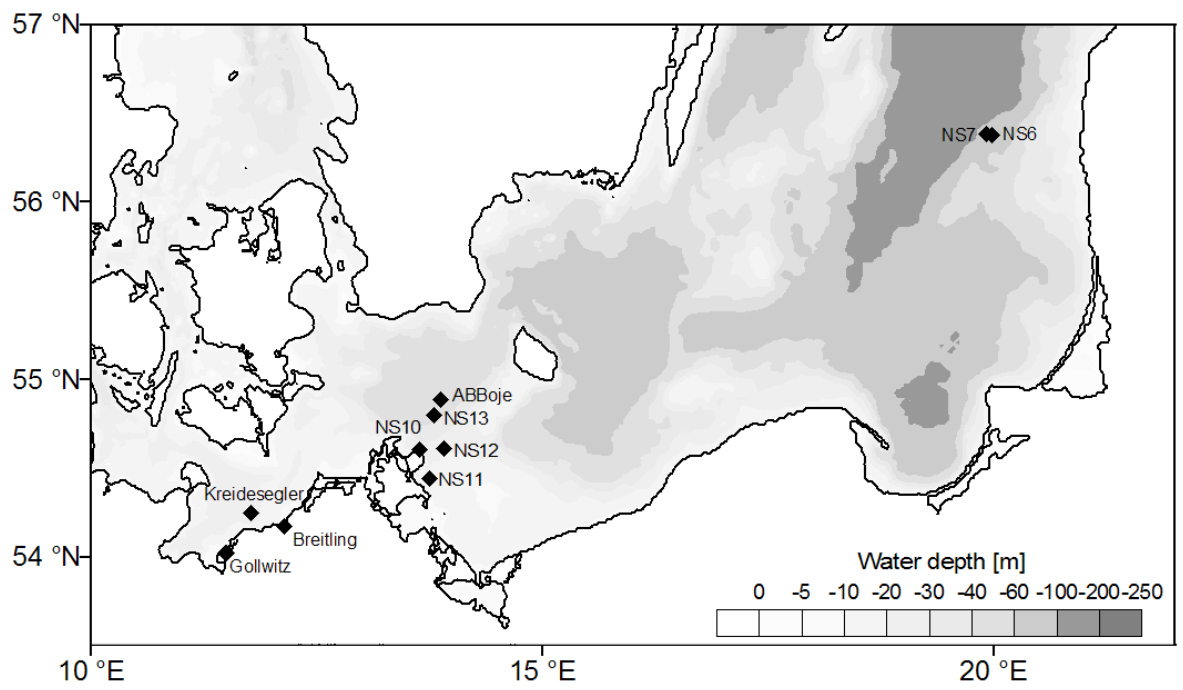

Fig. 1. Map showing the stations in the western and central Baltic Sea.

too low oxygen levels as a result of high in-situ temperatures $\left(15-23^{\circ} \mathrm{C}\right)$. Oxygen levels in overlying water were routinely checked using $\mathrm{O}_{2}$-microelectrodes and remained above $60 \%$ saturation during the incubations. After the incubation, the sediment of each core was homogenized. Samples of the sediment slurry were taken with a $50 \mathrm{ml}$ syringe and filled in $12 \mathrm{ml}$ exetainers (Labco). $100 \mu \mathrm{l}$ of zinc chloride solution was added to the samples to inhibit further bacterial activity. Finally, the exetainers were capped bubble-free and stored dry at room temperature prior to analysis. Concentrations of ${ }^{29} \mathrm{~N}_{2}$ and ${ }^{30} \mathrm{~N}_{2}$ were analyzed at the National Environmental Research Institute in Silkeborg (NERI, Denmark).

For the calculation of denitrification rates, the porosity $(\phi)$ of the sediment was determined by drying at $60^{\circ} \mathrm{C}$ overnight. Calculation was performed following Pettijohn et al. (1973) from fresh and dry weights assuming a solid matter specific density of $2.65 \mathrm{~g} \mathrm{~cm}^{-3}$.

\subsection{Testing the assumptions underlying the isotope pairing technique}

There are four conditions that should be met for a successful application of the isotope pairing technique (Steingruber et al., 2001). First, the added ${ }^{15} \mathrm{NO}_{3}^{-}$should not interfere with denitrification of in-situ $\mathrm{NO}_{3}^{-}$. If anammox is present this condition is not fulfilled and an increase of $\mathrm{N}_{2}$ production with tracer concentration can be observed. The second condition is that total denitrification of $\mathrm{NO}_{3}^{-}$from the water column should increase linearly with the $\mathrm{NO}_{3}^{-}$concentration in the overlying water (first order kinetics of denitrification). Furthermore, it must be ensured that the labelling of in-situ $\mathrm{NO}_{3}^{-}$with ${ }^{15} \mathrm{NO}_{3}^{-}$in the water column and in the sediment must be homogenous. Finally, a stable $\mathrm{NO}_{3}^{-}$concentration gradient across the sediment water interface must be established shortly after ${ }^{15} \mathrm{NO}_{3}^{-}$addition.

All four conditions are met when genuine $\mathrm{N}_{2}$ production $\left(\mathrm{p}_{14}\right)$ is independent of tracer concentration and the production of ${ }^{15} \mathrm{~N}-\mathrm{N}_{2}$ increases linearly with tracer concentration.

There was no tracer concentration dependency of genuine $\mathrm{N}_{2}$ production detected at any of the study sites (ANOVA, $p \gg 0.05)$. Therefore, the first assumption of the isotope pairing technique could be validated and provides a negative proof of anammox for all study sites. Furthermore, the linear regression of the ${ }^{15} \mathrm{~N}-\mathrm{N}_{2}$ production versus tracer concentration yielded a significant positive linear relationship for all stations $\left(R^{2}>0.88\right)$. Thus, the assumptions underlying the isotope pairing technique could be assumed to be valid.

\subsection{Statistical analysis}

The data were analysed using empirical orthogonal functions (EOFs) analysis (Preisendorfer, 1988). This multivariate statistical technique allows the extraction of the dominant overall pattern in the data set by reducing the dimensionality and the noise. The dimension of the raw data is reduced to few leading eigenmodes that account for the majority of the variance. The noise subspace is neglected. Consider a data vector $\boldsymbol{X}^{\prime}$ of anomalies:

$\boldsymbol{X}^{\prime}($ no, st $)=\sum_{\mathrm{i}=1}^{\mathrm{R}} \boldsymbol{P}_{\mathrm{i}}($ no $) \alpha_{\mathrm{i}}(\mathrm{st})+$ noise

Where "no" is the number of observations and "st" is the number of stations. " $\mathrm{P}_{i}$ " are the leading $\mathrm{R}$ eigenmodes depending only on the observations and " $\alpha_{i}$ " are fitting coefficients for each stations. A correlation analysis is performed between the fitting coefficients of the stations. 


\subsection{Calculating the annual $\mathrm{N}$-loss}

The denitrification rates from this study were used in 5 different approaches to calculate $\mathrm{N}$-removal rates for the entire Baltic Sea or several sub basins.

For the first three approaches, two different sediment distribution maps - each of them distinguishing between five different sediment types - were used.

For approach 1, the combined information from a Balticwide basin topography (Seifert et al., 2001), a sediment map compiled by B. Bobertz during the project DYNAS (dynamics of natural and anthropogenic sedimentation) and the average distribution of oxygen in the bottom water (1960-1990 means from IOW MOM3/ERGOM model results; Seifert pers. communication) was used. Hence, it was possible to exclude all areas from the calculation where oxygen was zero or $\mathrm{H}_{2} \mathrm{~S}$ present. Sediments are classified according to median diameter into five sediment types: silt/clay, fine sand, medium sand, coarse sand and hard rock. Our sampled stations were allocated to a certain sediment type according to their positions on the map. If large discrepancies occurred between the measured sediment characteristics and the allocated sediment type according to the map, the station was then allocated according to its sediment characteristics (Table 1).

The mean, maximum, and minimum $\mathrm{N}$-removal rates were calculated. For the calculation of the mean value, the average value of all denitrification rates for the same sediment type was used. For calculation of the maximum and minimum Nremoval, only the highest and lowest denitrification rates of each group were used, respectively.

The dataset used for the approaches 2 and 3 was a sediment map published in the BALANCE interim report No. 10 (Al-Hamdani and Reker, 2007). This map also contains 5 sediment types (mud, hard clay, sand, hard bottom complex and bedrock). The area covered by each sediment type was estimated using GIS. To account for inhibited denitrification in sediments below anoxic water bodies, we excluded all sediments in the southern and central Baltic as well as in the Gulf of Finland with water depths $\geq 100 \mathrm{~m}$.

For approach 3, we estimated the changes in the $\mathrm{N}$ removal capacity of the Baltic Sea under increasing anoxic bottom areas. For this approach, we simulated a rise in the oxycline from $100 \mathrm{~m}$ water depth which is close to the recent state to $80 \mathrm{~m}$ by excluding all areas in the Baltic Proper and the Gulf of Finland with water depths $\geq 80 \mathrm{~m}$.

For both approaches, the allocation of the stations to a certain sediment type was performed the same way as for the first approach (Table 1). The calculation of the mean, maximum, and minimum $\mathrm{N}$-removal was performed in analogy to approach 1 as well.

The results from approach 2 were furthermore used together with data from other studies of nitrogen inputs and nitrogen removal (Brettar and Rheinheimer, 1991; Emeis et al., 2000; Wasmund et al., 2001; Savchuk, 2005; Wulff et al.,

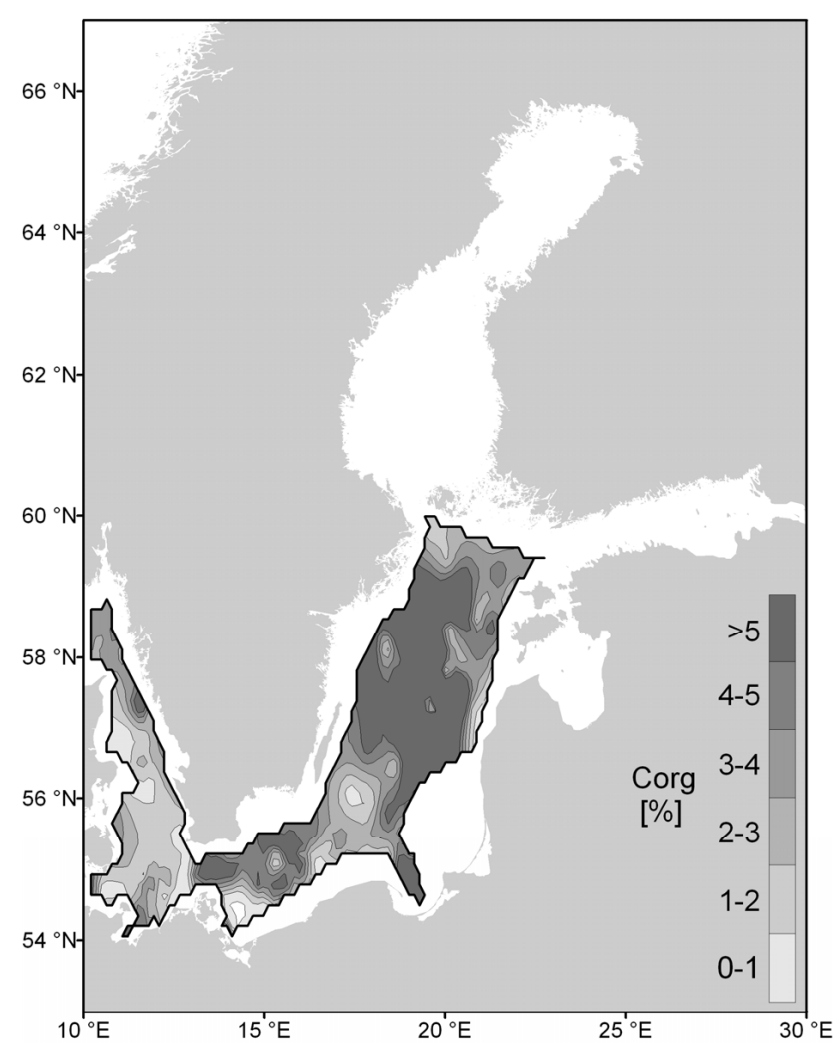

Fig. 2. Map showing the $\mathrm{C}_{\text {org }}[\%]$ distribution for parts of the Baltic Sea.

2009) to set up a nitrogen budget for the Baltic Sea sub-basin Baltic Proper.

For the approaches 4 and 5, we used a correlation between our measured denitrification rates and the $\mathrm{C}_{\text {org }}$ contents of the surface sediments. A large dataset of $\mathrm{C}_{\text {org }}$ [\%] measurements of surface sediments $(n=551)$ was available for this approach (Leipe et al., 2010). The $\mathrm{C}_{\text {org }}$ data were arranged into 6 groups $\left(\mathrm{C}_{\text {org }}\right.$ : $0-1 \%, 1-2 \%, 2-3 \%, 3-4 \%, 4-$ $5 \%,>5 \%$ ) and a map showing the $\mathrm{C}_{\text {org }}$ content was created (Fig. 2). This map was digitalized and the area of every $\mathrm{C}_{\text {org }}$ group was calculated using GIS. Since the $\mathrm{C}_{\text {org }}$ data only covered parts of the Skagerrak, the Kattegat, and the western, southern, and central Baltic (total area: $110482 \mathrm{~km}^{2}$ ), we only calculated an N-removal rate for this area. The calculated areas for the different $\mathrm{C}_{\text {org }}$ concentrations were: 0 1\%: $10120 \mathrm{~km}^{2}, 1-2 \%: 18538 \mathrm{~km}^{2}, 2-3 \%: 20947 \mathrm{~km}^{2}, 3-$ 4\%: $23070 \mathrm{~km}^{2}, 4-5 \%: 16411 \mathrm{~km}^{2}$, and $>5 \% 21396 \mathrm{~km}^{2}$. For those parts not covered by the $\mathrm{C}_{\text {org }} \operatorname{map}\left(161000 \mathrm{~km}^{2}\right.$, which are mainly the Gulf of Riga, the area off Lithuania, and the coastal regions of Poland, Germany, Denmark, and south and west Sweden), we arbitrarily assumed a $\mathrm{C}_{\text {org }}$ content of $0-1 \%$ (approach 4) or 1-2\% (approach 5). This assumes that sediments classified as sand may be respectively more or less winnowed by waves and currents acting to reduce their organic carbon content (e.g. Sakamaki and Nishimura, 
Table 1. Allocation of the sampled stations to various sediment types of the respective sediment map.

\begin{tabular}{|c|c|c|c|c|c|}
\hline \multicolumn{3}{|c|}{ Approach 1} & \multicolumn{3}{|c|}{ Approaches 2 and 3} \\
\hline $\begin{array}{l}\text { Sediment type } \\
\left(\mathrm{O}_{2}>0\right)\end{array}$ & $\begin{array}{r}\text { Area } \\
{\left[\mathrm{km}^{2}\right]}\end{array}$ & Allocated stations & $\begin{array}{l}\text { Sediment type } \\
(\text { depth } \leq 100 \mathrm{~m})\end{array}$ & $\begin{array}{r}\text { Area } \\
{\left[\mathrm{km}^{2}\right]}\end{array}$ & Allocated stations \\
\hline fine sand & 43316 & NS6, NS7, NS10 & hard clay & 83255 & NS6, NS7 \\
\hline medium sand & 64367 & NS11, NS12 & sand & 88826 & Breitling, Gollwitz $1 \&$ 2, NS12 \\
\hline coarse sand & 20646 & Breitling, Gollwitz 1, Gollwitz 2 & hard bottom complex & 65465 & Excluded (no denitrification) \\
\hline
\end{tabular}

Table 2. Stations, sampling date, water depth, temperature, oxygen and nitrate concentrations of bottom water, organic carbon content of the surface sediments as well as median grain size, task sorting coefficient, and sediment type.

\begin{tabular}{|c|c|c|c|c|c|c|c|c|c|}
\hline Station & Date & $\begin{array}{l}\text { Depth } \\
{[\mathrm{m}]}\end{array}$ & $\begin{array}{c}\text { Bottom } \\
\text { Temperature } \\
{\left[{ }^{\circ} \mathrm{C}\right]}\end{array}$ & $\begin{array}{c}\text { Bottom } \\
\text { Oxygen } \\
{\left[\mu \mathrm{mol} \mathrm{l}^{-1}\right]}\end{array}$ & $\begin{array}{c}\text { Bottom } \\
\text { Nitrate } \\
{\left[\mu \mathrm{mol} \mathrm{l}^{-1}\right]}\end{array}$ & $\begin{array}{c}\mathrm{C}_{\text {org }} \text { content of } \\
\text { surface } \\
\text { sediment }[\%]\end{array}$ & $\begin{array}{l}\text { Median } \\
\text { Grain } \\
\text { size }[\mu \mathrm{m}]\end{array}$ & $\begin{array}{c}\text { Trask } \\
\text { sorting } \\
\text { coefficient }\end{array}$ & $\begin{array}{l}\text { Sediment } \\
\text { Type }\end{array}$ \\
\hline ABBoje & Aug-08 & 46 & 14.6 & 85.7 & 5.2 & 5.54 & 10.8 & 1.3 & alluvial mud \\
\hline ABBoje & Nov- 08 & 46 & 12.2 & 183.1 & 4.3 & 3.75 & 11.1 & 1.4 & alluvial mud \\
\hline Kreidesegler & May 08 & 15 & 5.3 & 236.2 & 2.5 & 4.53 & 9.5 & 1.2 & alluvial mud \\
\hline NS13 & Nov-08 & 47 & 12.2 & 216.2 & 3.1 & 4.08 & 13.3 & 1.3 & alluvial mud \\
\hline NS 10 & Nov-08 & 25 & 11.3 & 242.4 & 1.9 & 2.58 & 30.8 & 1.1 & silt/mud \\
\hline NS11 & Nov-08 & 22 & 12.4 & 206.4 & 4.7 & 0.79 & 141.1 & 0.5 & silt/fine sand \\
\hline NS7 & Aug-08 & 80 & 5.5 & 80.8 & 6.3 & 3.76 & 24.5 & 1.5 & glacial drift, alluvial mud \\
\hline NS6 & Aug-08 & 75 & 5.2 & 99.1 & 6.6 & 1.15 & $42.4(14.6)$ & $1.3(1.6)$ & glacial drift (boulder clay) \\
\hline NS12 & Nov-08 & 22 & 10.1 & 309.3 & 0.3 & 0.06 & 192.5 & 0.3 & fine sand \\
\hline Gollwitz 2 & Sep-08 & 0.2 & 15.3 & 354.1 & 1.2 & 0.46 & 87.5 & 0.6 & muddy sand \\
\hline Gollwitz 1 & Sep-08 & 0.2 & 15.3 & 354.1 & 1 & 0.23 & 107.5 & 0.5 & sand \\
\hline Breitling & $\begin{array}{r}\text { Jul-08 } \\
\text { Jul }\end{array}$ & 0.2 & 22.6 & 311.5 & 0.3 & 0.26 & 165 & 0.7 & fine sand \\
\hline
\end{tabular}

Table 3. Calculated sediment specific denitrification rates as well as calculated mean, maximum, and minimum annual N-removal.

\begin{tabular}{|c|c|c|c|c|c|c|}
\hline Approach & & 1 & 2 & 3 & 4 & 5 \\
\hline Used data for interpolation of rates & & $\begin{array}{l}\text { entire } \\
\text { Baltic Sea } \\
\text { DYNAS map, } \\
\text { MOM3/ERGOM bottom } \\
\text { oxygen }\end{array}$ & $\begin{array}{l}\text { entire } \\
\text { Baltic Sea } \\
\text { BALANCE } \\
\text { sediment map }\end{array}$ & $\begin{array}{l}\text { entire } \\
\text { Baltic Sea } \\
\text { BALANCE } \\
\text { sediment map }\end{array}$ & $\begin{array}{l}\text { western, } \\
\text { southern and } \\
\text { central Baltic } \\
\text { C }_{\text {org }} \text { map }\end{array}$ & $\begin{array}{l}\text { western, } \\
\text { southern and } \\
\text { central Baltic } \\
\mathrm{C}_{\text {org map }}\end{array}$ \\
\hline $\begin{array}{l}\text { Calculated mean sediment } \\
\text { denitrification rates } \\
\text { specific }\left[\mu \mathrm{mol} \mathrm{Nm} \mathrm{Nm}^{-2} \mathrm{~h}^{-1}\right]\end{array}$ & & $\begin{array}{l}\text { silt/clay: } 21.58 \pm 5.95 \\
\text { fine sand: } 9.73 \pm 4.70 \\
\text { medium sand: } 8.94 \pm 4.45 \\
\text { coarse sand: } 1.38 \pm 0.80\end{array}$ & \multicolumn{2}{|c|}{$\begin{array}{c}\text { mud: } 19.34 \pm 6.13 \\
\text { hard clay: } 6.42 \pm 10.47 \\
\text { sand: } 2.15 \pm 1.33\end{array}$} & \multicolumn{2}{|c|}{$\begin{array}{c}\text { calculated from regression equation } \\
\text { equation }\end{array}$} \\
\hline \multirow{3}{*}{$\begin{array}{l}\text { Calculated } \mathrm{N} \text { removal from } \\
\text { sediments }\left[\mathrm{kt} \mathrm{a}^{-1}\right]\end{array}$} & Mean & 652 & 426 & 367 & 297 & 374 \\
\hline & $\operatorname{Max}$ & 899 & 618 & 532 & 379 & 474 \\
\hline & Min & 380 & 287 & 247 & 232 & 327 \\
\hline
\end{tabular}




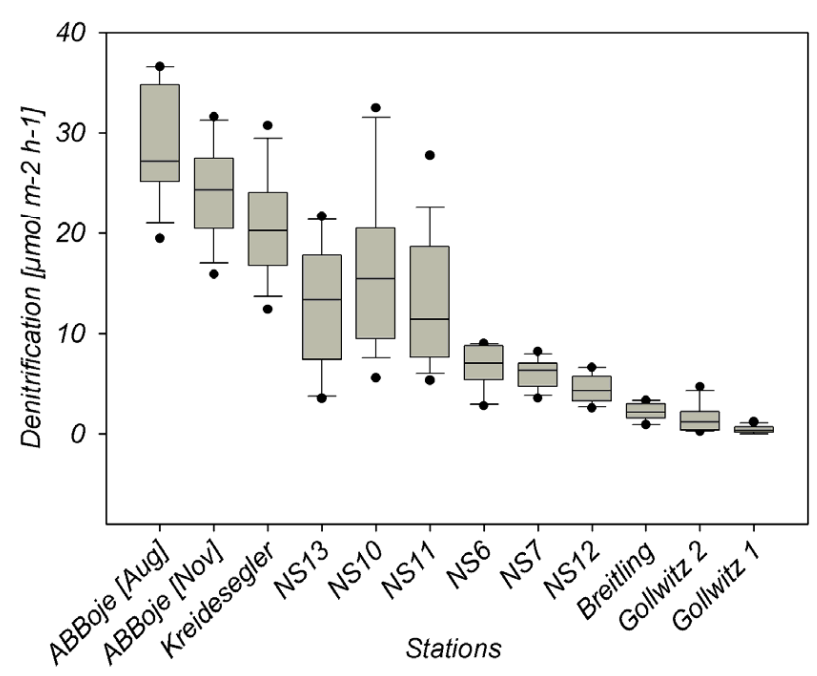

Fig. 3. Box-Whisker-Plots of denitrification rates for all stations, showing median, lower and upper quartile, extremes, and outliers.

2007). The significant regression between denitrification and organic carbon was used to calculate the mean, maximum, and minimum denitrification rates for every $\mathrm{C}_{\mathrm{org}}$ group. For the calculation of the mean denitrification rate, the median $\mathrm{C}_{\text {org }}$ values were used (for group $0-1 \%$ : 0.5 , for group: $1-$ $2 \% 1.5$, and so on). The maximum and minimum denitrification rates were calculated by means of the maximum ( $1 \%$, $2 \%, 3 \%, 4 \%, 5 \%, 6 \%)$ and minimum $(0 \%, 1 \%, 2 \%, 3 \%, 4 \%$, $5 \%$ ) values of each group. As described for approaches 2 and 3, we excluded all sediments with water depths $\geq 100 \mathrm{~m}$ in the southern and central Baltic and the Gulf of Finland.

\section{Results}

\subsection{Rates of sedimentary denitrification and environmental parameters}

Highest denitrification rates were found at the central station in the Arkona Basin (ABBoje: $28.71 \mu \mathrm{mol} \mathrm{N} \mathrm{m}{ }^{-2} \mathrm{~h}^{-1}$ in summer and $24.42 \mu \mathrm{mol} \mathrm{N} \mathrm{m}{ }^{-2} \mathrm{~h}^{-1}$ in autumn; Fig. 3) and there was no significant difference in the rates between the two sampling dates (2-tailed t-test, $p \gg 0.05$ ). At the two other stations with muddy sediments (Kreidesegler and NS13), denitrification rates were lower, being 20.58 and $12.58 \mu \mathrm{mol} \mathrm{N} \mathrm{m} \mathrm{N}^{-2} \mathrm{~h}^{-1}$, respectively. The silt stations (NS10 and NS11) showed rates between 16.37 and $13.40 \mu \mathrm{mol} \mathrm{N} \mathrm{m} \mathrm{m}^{-2} \mathrm{~h}^{-1}$. At the two stations in the Gotland Basin (NS6 and NS7), rates were significantly lower -6.75 and $6.08 \mu \mathrm{mol} \mathrm{N} \mathrm{m}^{-2} \mathrm{~h}^{-1}$ (2-tailed t-test, $p<0.05)$. The lowest denitrification rates were measured in sandy sediments from the edge of the Arkona Basin (NS12: $4.49 \mu \mathrm{mol} \mathrm{N} \mathrm{m}^{-2} \mathrm{~h}^{-1}$ ) and from the near shore stations Breitling $\left(2.5 \mu \mathrm{mol} \mathrm{N} \mathrm{m} \mathrm{m}^{-2} \mathrm{~h}^{-1}\right)$, Gollwitz 1 $\left(0.5 \mu \mathrm{mol} \mathrm{N} \mathrm{m} \mathrm{m}^{-2} \mathrm{~h}^{-1}\right)$, and Gollwitz $2\left(1.1 \mu \mathrm{mol} \mathrm{N} \mathrm{m}{ }^{-2} \mathrm{~h}^{-1}\right)$.

Physico-chemical characteristics of the study sites are shown in Table 2. Bottom water temperatures varied from approximately $5^{\circ} \mathrm{C}$ (Kreidesegler, NS6 and NS7) to $15^{\circ} \mathrm{C}$ (Gollwitz 1, Gollwitz 2 and ABBoje) and $23^{\circ} \mathrm{C}$ (Breitling), respectively. Oxygen was present in the bottom water of all study sites with lowest concentrations (80.8 to $99.1 \mu \mathrm{mol}^{-1}$ ) in the central Baltic at stations NS6, NS7, and ABBoje during summer and highest concentration above saturation at stations Gollwitz 1 and Gollwitz $2\left(354.1 \mu \mathrm{mol} \mathrm{l}^{-1}\right)$. During the November sampling campaign, oxygen concentrations were $183.1-309.2 \mu \mathrm{mol} \mathrm{l}^{-1}$ with lowest concentrations found at station ABBoje and highest concentrations at NS12. Nitrate concentrations in the near-bottom water were close to detection limit at the coastal stations Breitling, Gollwitz 1 and Gollwitz $2\left(0.3-1.2 \mu \mathrm{mol}^{-1}\right)$. Highest concentrations were found in the Gotland Basin at station NS6 and NS7 with 6.6 and $6.3 \mu \mathrm{mol}^{-1}$, respectively. Summer and autumn concentrations of $\mathrm{NO}_{3}^{-}$at $\mathrm{ABBoje}$ were only slightly different with 5.2 and $4.3 \mu \mathrm{moll}^{-1}$, respectively. Organic carbon content varied according to sediment type, with highest values found at the mud stations ABBoje, Kreidesegler, and NS13 (3.75-5.54\%), followed by the mixed sediments NS6, NS7, NS10, NS11 (0.79-3.76\%) and sandy sediment stations Breitling, Gollwitz 1, Gollwitz 2 and NS12 (0.06-0.46\%).

A significant correlation between the denitrification rate and the possible controlling environmental parameters could be found for the organic carbon content of the surface sediments (denitrification $=1.3061 \times \mathrm{C}_{\text {org }}+0.8903, R^{2}=0.67$, $p<0.001)$.

After noise reduction denitrification rate is significantly correlated with $\mathrm{C}_{\text {org }}(R=0.83, p<0.001, n=12), \mathrm{N}_{\text {org }}$ $(R=0.79, p<0.01, n=12), \mathrm{C}: \mathrm{N}$ ratio $(R=0.62, p<$ $0.05, n=12)$ and grain size $(R=-0.63, p<0.05, n=12)$ (Fig. 4). Since we found the highest correlation coefficient for $\mathrm{C}_{\text {org }}$ this value was chosen for the extrapolation purpose.

\subsection{Calculation of the annual N-removal}

The results of all approaches together with the calculated sediment specific denitrification rates are summarized in Table 3. For the approaches by means of the sediment types $(1,2$, and 3) which were performed for the entire Baltic Sea area, the highest $\mathrm{N}$-removal was calculated from approach 1 with a mean of $652 \mathrm{kt} \mathrm{N} \mathrm{a}^{-1}$. The maximum and minimum values were 899 and $380 \mathrm{kt} \mathrm{Na}^{-1}$, respectively. For approach 2, the mean $\mathrm{N}$-removal rate was $426 \mathrm{kt} \mathrm{Na}^{-1}$ (max: $618 \mathrm{kt} \mathrm{Na}^{-1}$, min: $287 \mathrm{kt} \mathrm{Na}^{-1}$ ), which is $35 \%$ lower compared to the mean rate calculated by approach 1 .

A rise of the oxycline from 100 to $80 \mathrm{~m}$ water depth and the resulting expansion of the anoxic sea bottom areas, as simulated in approach 3, would lead to a N-removal rate of $367 \mathrm{kt} \mathrm{Na}^{-1}\left(\max : 532 \mathrm{kt} \mathrm{Na}^{-1}, \min : 247 \mathrm{kt} \mathrm{Na}^{-1}\right)$. 
Table 4. N-removal via sedimentary denitrification per basin calculated via approaches 2 (oxycline at $100 \mathrm{~m}$ ) and 3 (oxycline at $80 \mathrm{~m}$ ) and the reduction of the $\mathrm{N}$-removal as a result of a rise of the oxycline (mean $\mathrm{N}$-removal from approach 2 minus mean $\mathrm{N}$-removal from approach 3).

\begin{tabular}{|c|c|c|c|c|c|}
\hline Basin & $\begin{array}{r}\text { mean } \mathrm{N} \text { removal } \\
\text { from sediments } \\
{\left[\mathrm{t} \mathrm{a}^{-1}\right]} \\
(\text { approach } 2)\end{array}$ & $\begin{array}{r}\max . \mathrm{N} \text { removal } \\
\text { from sediments } \\
{\left[\mathrm{t} \mathrm{a}^{-1}\right]} \\
(\text { approach } 2)\end{array}$ & $\begin{array}{r}\min . \mathrm{N} \text { removal } \\
\text { from sediments } \\
{\left[\mathrm{t} \mathrm{a}^{-1}\right]} \\
(\text { approach } 2)\end{array}$ & $\begin{array}{r}\text { mean } \mathrm{N} \text { removal } \\
\text { from sediments } \\
{\left[\mathrm{t} \mathrm{a}^{-1}\right]} \\
(\text { approach } 3)\end{array}$ & $\begin{array}{r}\text { reduction } \\
{[\%]}\end{array}$ \\
\hline Kattegatt & 52 & 79 & 33 & 52 & 0 \\
\hline Belt Sea + western Baltic & 24 & 37 & 15 & 24 & 0 \\
\hline Baltic Proper (excl. Gulf of Riga) & 191 & 277 & 129 & 133 & 30 \\
\hline Gulf of Riga & 23 & 35 & 14 & 23 & 0 \\
\hline Gulf of Finland & 38 & 54 & 26 & 36 & 4 \\
\hline Bothnian Sea & 63 & 85 & 48 & 63 & 0 \\
\hline Bothnian Bay & 35 & 53 & 23 & 35 & 0 \\
\hline
\end{tabular}

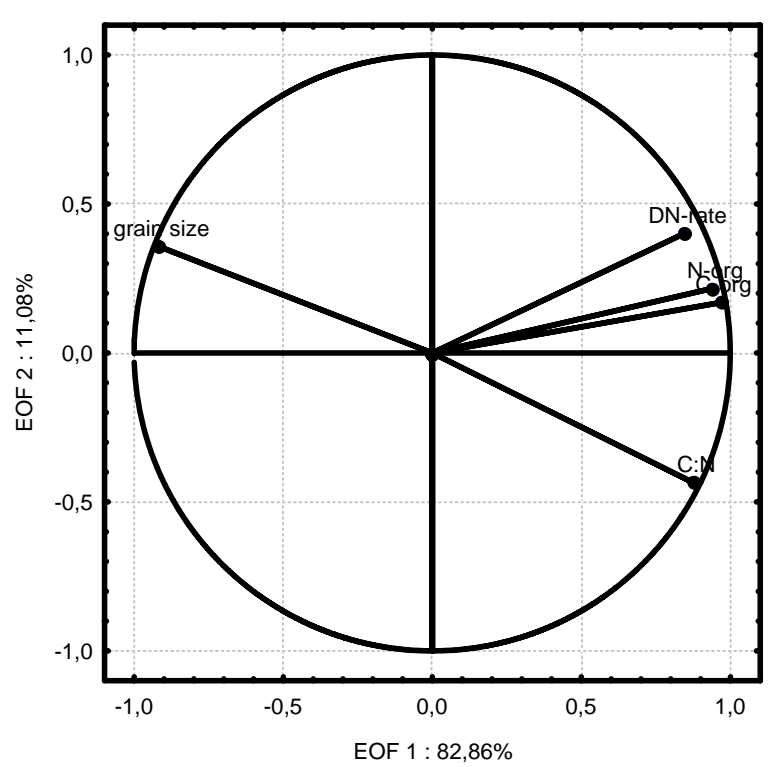

Fig. 4. Projection of the fitting coefficients in EOF coordinates.

Compared to $426 \mathrm{kt} \mathrm{N} \mathrm{a}^{-1}$, this is equivalent to a reduction of $14 \%$. For the approaches 2 and 3, it was possible to estimate the N-removal for the several sub basins of the Baltic Sea shown in Table 4. The highest N-removal rates were found in the sub basin "Baltic Proper", followed by the "Bothnian Sea" and the sub basin "Kattegatt". It also becomes obvious that a rise in the oxycline only influences the $\mathrm{N}$ loss from the sub basins "Baltic Proper" (reduction of 30\%) and to a much lesser extent the "Gulf of Finnland" (reduction of 4\%).

The approaches 4 and 5 were carried out by means of the $\mathrm{C}_{\text {org }}$ distribution map for the western, southern, and central Baltic only. The mean rates were $297 \mathrm{kt} \mathrm{Na}^{-1}$ (max: $379 \mathrm{kt} \mathrm{Na}^{-1}$, min: $232 \mathrm{kt} \mathrm{N} \mathrm{a}^{-1}$, Table 3) when the remaining area outside the $\mathrm{C}_{\text {org }}$ distribution map is calculated with a $\mathrm{C}_{\text {org }}$ content of $0-1 \%$. If the outside area is calculated with a $\mathrm{C}_{\text {org }}$ content of $1-2 \%$, the mean $\mathrm{N}$-removal rate increases to $374 \mathrm{kt} \mathrm{N} \mathrm{a}^{-1}$ (max: $474 \mathrm{kt} \mathrm{N} \mathrm{a}^{-1}$, $\min : 326 \mathrm{kt} \mathrm{N} \mathrm{a}^{-1}$ ).

\section{Discussion}

Since denitrification in sediments is assumed to be the dominant N-removal process for the Baltic Sea (Shaffer and Rönner, 1984), the understanding of the controlling factors and an estimate of the total N-removal rate for the entire Baltic Sea basin is a major need for evaluating the current status (in terms of nutrient input and sequestration) and future development of this ecosystem.

\subsection{Factors controlling the rate of denitrification in Baltic Sea sediments}

It has been shown that benthic denitrification can be controlled by temperature, nitrate availability, and supply of organic carbon (Nowicki et al., 1997; Kana et al., 1998), but, commonly a combination of various parameters is responsible for controlling the rate of denitrification in sediments (Seitzinger, 1988; Piña-Ochoa and Álvarez-Cobelas, 2006). An increase in temperature for instance can directly result in an increase in the rate of denitrification, but, can also increase the nitrification rate which then additionally enhances the supply of nitrate (Seitzinger, 1988). A seasonal variation in denitrification can be observed frequently and is reported for Baltic Sea sediments (Tuominen et al., 1998; Sundbäck et al., 2000; Hietanen and Kuparinen 2008) as well as for other regions (Nowicki et al., 1997; Cabrita and Brotas, 2000; Dong et al., 2000). For the Gulf of Finland, Hietanen and Kuparinen (2008) found a seasonal cycle with higher rates during autumn and early winter, whereas Tuominen et al. (1998) measured the highest rates in late summer and early autumn. Kähler (1990) measured the highest rates in the Kiel Bight during spring. Most probably, the causes for these seasonal variations are mainly combinations of several controlling environmental parameters like higher temperatures and 
an increased supply of organic carbon in post-bloom-periods (Nowicki et al., 1997). Therefore, it can be expected that at our stations a seasonal variation in denitrification exists as well.

We could not detect any seasonality in our rates mainly because our investigations were all carried out during late summer and autumn. Moreover, our results suggest that the spatial variation of the denitrification rates is primary controlled by the organic carbon content of the surface sediments. This was also reported by Trimmer and Nicholls (2009) for a study from the Irish shelf to the North Atlantic where they found a positive correlation between sedimentary denitrification and $\mathrm{C}_{\text {org }}$ content of surface sediments.

We did not find a correlation between the rate of denitrification and the concentration of nitrate in the overlying water which suggests that denitrification at most stations was fueled by nitrate which was generated during nitrification in the overlying sediment. This assumption was supported by the fact that the share of the coupled nitrification-denitrification $\left(\mathrm{D}_{n}\right)$ to total denitrification was over $70 \%$ at 8 out of 12 stations (data not shown) which implies that an intense coupling between remineralisation of the organic matter in the sediments and the denitrification took place at almost all stations.

\subsection{Nitrogen removal calculated from different sediment maps}

The total N-loss via sedimentary denitrification for the Baltic Sea estimated from our approaches by means of sediment distribution maps (approaches 1 and 2) ranges between 426 and $652 \mathrm{kt} \mathrm{N} \mathrm{a}^{-1}$ (Table 3). This means that between $48 \%$ to $73 \%$ of the annual $\mathrm{N}$-input delivered by rivers, coastal point sources, and atmospheric deposition to the Baltic Sea is removed via sedimentary denitrification. A direct comparison with studies from other regions is difficult because a similar approach has not been applied anywhere else. Boynton et al. (1995) estimated with their conceptual model for the Chesapeake Bay system a total $\mathrm{N}$-loss via denitrification of $40 \mathrm{kt} \mathrm{N} \mathrm{a}^{-1}$ which is $26 \%$ of the total $\mathrm{N}$ inputs and lower than our estimates.

The mean rate calculated from approach 1 is $226 \mathrm{kt} \mathrm{N}$ higher than the one from approach 2 . This difference seems to be the result of a higher areal percentage of muddy sediments in the sediment distribution map from the DYNAS project (50\% of oxic area) which was used for approach 1 compared to the map from the BALANCE project (36\% of oxic area) used for approach 2 . In muddy sediments the highest denitrification rates were measured.

Based on approach 2, it was possible to calculate Nremoval rates for single sub-basins of the Baltic Sea (Table 4) and to compare them with rates presented from other studies (Table 5).

The annual N-removal of $39 \mathrm{kt} \mathrm{N}$ for the Gulf of Finland calculated by Hietanen and Kuparinen (2008) matches very well with our estimated annual $\mathrm{N}$ loss for the same area
$(38 \mathrm{kt})$. For the same area, Tuominen et al. (1998) estimated a removal of $45 \mathrm{kt} \mathrm{N}$ which is slightly higher, but, well within the range of our calculated minimum and maximum N-removal rates. The rates for the Bothnian Bay (15 kt N) and Bothnian Sea ( $35 \mathrm{kt} \mathrm{N})$ by Stockenberg and Johnstone (1997) were much lower than our calculations of 35 and $63 \mathrm{kt} \mathrm{N}$, respectively. In that study, denitrification rates were measured with the "acetylene block" method which is known to underestimate denitrification rates compared to the now standard "Isotope Pairing Technique" because of an acetylene inhibition of the nitrification process which can be an important source for nitrate in the denitrification pathway (Seitzinger et al., 1993; Lohse et al., 1996; Steingruber et al., 2001). The coupled nitrification-denitrification in sediments $\left(D_{n}\right)$ often exceeds the type of denitrification that is based on the diffusion of nitrate from the overlying water into the sediment $\left(\mathrm{D}_{w}\right)$ and can reach a contribution of more than $90 \%$ to total denitrification (Lohse et al., 1996; Tuominen et al., 1998; Hietanen and Kuparinen, 2008) similar to our findings. Therefore, it cannot be excluded that the rates measured by Stockenberg and Johnstone (1997) were lower than the real rates and that the extrapolated $\mathrm{N}$-removal was underestimated.

All three available studies (Shaffer and Rönner, 1984; Eiola and Stigebrandt, 1999; Voss et al., 2005; Table 5) that calculated a N-loss via denitrification for the Baltic Proper did not distinguish between sedimentary and water column denitrification and, therefore, are hardly comparable with our results. The largest hypoxic water-body of the Baltic Sea is located in that area and water-column denitrification might play an important role in the total $\mathrm{N}$-losses from the system.

As a rough estimate of total water column denitrification in the Baltic Proper, we extrapolate the rates reported by Brettar and Rheinheimer (1991) measured with the "acetylene block" method. They found in the Central Gotland Basin 110 and $44 \mathrm{nmol} \mathrm{N}^{-1} \mathrm{~d}^{-1}$ in 1986 and 1987, respectively. Since denitrification was measurable at oxygen concentrations between $0-17.8 \mu \mathrm{mol}^{-1}$, we calculated a total $\mathrm{N}$-removal rate in the water column for the water body with oxygen concentrations between 0 to $17.8 \mu \mathrm{mol} 1^{-1}$. This gives us a total volume of $524.39 \mathrm{~km}^{3}$ (period between January 2005 to December 2006; Source: Baltic Nest Institute, Stockholm) where we assumed a mean denitrification rate of $77 \mathrm{nmol} \mathrm{N} \mathrm{l}^{-1}$ $\mathrm{d}^{-1}$ and a maximum rate of $110 \mathrm{nmolN}^{-1} \mathrm{~d}^{-1}$. The mean and maximum annual N-removals then account for 206 and $294 \mathrm{kt} \mathrm{N}$, respectively. Adding our sedimentary rates from approach 2, this gives a total mean and maximum N-removal by denitrification for the Baltic Proper of 397 and $571 \mathrm{kt} \mathrm{N}$ allocating equal parts of denitrification to sedimentary and water column processes. These numbers are in the same order of magnitude as the rates reported from the other studies (Shaffer and Rönner, 1984; Eiola and Stigebrandt, 1999; Voss et al., 2005). 
Table 5. N-removal rates from other studies for several sub basins of the Baltic Sea.

\begin{tabular}{|c|c|c|c|c|}
\hline Area & annual N-removal [kt N] & Sediment/water column & Method & Reference \\
\hline Baltic Proper & $580-855$ & sediment + water column & stable isotope budget & (Voss et al., 2005) \\
\hline Baltic Proper & 470 & sediment + water column & mass balance calculations & (Shaffer and Rönner, 1984) \\
\hline Baltic Proper & 560 & sediment + water column & mass balance calculations & (Eilola and Stigebrandt, 1999) \\
\hline Gulf of Finland & 45 & sediment & extrapolation of "Isotope Pairing" rates & (Tuominen et al., 1998) \\
\hline Gulf of Finland & 39 & sediment & extrapolation of "Isotope Pairing" rates & (Hietanen and Kuparinen, 2008) \\
\hline Bothnian Sea & 35 & sediment & extrapolation of "Acetylene Block" rates & (Stockenberg and Johnstone, 1997) \\
\hline Bothnian Bay & 15 & sediment & extrapolation of "Acetylene Block" rates & (Stockenberg and Johnstone, 1997) \\
\hline
\end{tabular}

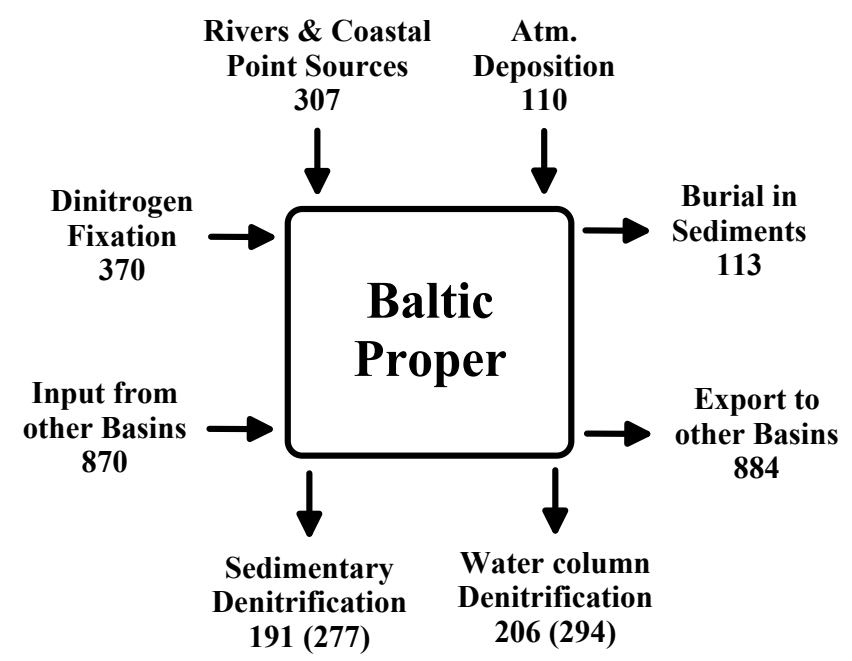

Fig. 5. N-Budget for the Baltic Proper (all values are given in $\mathrm{kt} \mathrm{Na}^{-1}$ ). Mean and maximum removal rates (in parentheses) by denitrification are presented.

Since detailed data for $\mathrm{N}$-inputs via nitrogen fixation are not available for the entire Baltic Sea, we set up a total N budget only for the Baltic Proper (Fig. 5). For this budget, we used data for $\mathrm{N}$ inputs via rivers, coastal point sources, and atmospheric deposition from Wulff et al. (2009). Data for $\mathrm{N}$-input via $\mathrm{N}_{2}$-fixation by cyanobacteria were taken from the study of Wasmund et al. (2001). The N-loss via burial of nitrogen in the sediments was taken from Emeis et al. (2000) and the import and export of nitrogen to and from other basins was taken from Savchuk (2005). For calculation of water column denitrification, we extrapolated the mean and maximum denitrification rate measured with the "acetylene block method" in the water column in the central Gotland Basin by Brettar and Rheinheimer (1991). The budget was also calculated with both, the mean and the maximum sediment denitrification rate from approach 3. The results show for the Baltic Proper that the $\mathrm{N}$ removal occurring through denitrification in the sediment is equivalent to the N-removal via water column denitrification. Furthermore, in view of the uncertainties associated with the extrapolations made, it seems that the budget is nearly balanced if calculated with the maximum denitrification rates (difference of $\sim 90 \mathrm{kt} \mathrm{N}$ between inputs and outputs). If calculated with the mean values, there exists an $\mathrm{N}$-excess of $263 \mathrm{kt}$ which might be buried into the sediments.

Our simulated rise in the oxycline from the recent depth of $100 \mathrm{~m}$ to $80 \mathrm{~m}$ water depth leads to an expansion of the area with anoxic sediments on the order of $30000 \mathrm{~km}^{2}$ which are mainly muddy sediments. These sediments offer conditions that are unfavorable for sedimentary denitrification which results in a total decrease of the N-removal rate by $14 \%$ (Table 4). The regions that are influenced by this reduction are the Baltic Proper (by 30\%) and the Gulf of Finland (by 4\%). All other areas are not impacted by this increase in the oxycline either because they are too shallow like the western Baltic or they do not have strong stratified water columns like the Bothnian Sea and Bothnian Bay.

It is widely accepted that besides the climate, the enhanced nutrient inputs are responsible for the expansion of the hypoxic and anoxic areas of the Baltic Sea in the last decades (Conley et al., 2009a). Furthermore, it is obvious that a reduction of the anoxic areas is only possible when the nutrient inputs into the Baltic Sea are strongly reduced. Although it can be assumed that an increase of hypoxic areas would lead to an increase of N-removal via water column denitrification (Conley et al., 2009a), our results demonstrate that increasing the areal coverage of anoxic sediment surfaces will lead to a drastic reduction of the $\mathrm{N}$-removal via sedimentary denitrification. This could be observed in the Gulf of Mexico where sedimentary denitrification was remarkably reduced at oxygen concentrations in the overlying water below $31.2 \mu \mathrm{mol}^{-1}$ (Childs et al., 2002). Furthermore, it could be observed that under highly reducing conditions, dissimilatory nitrate reduction to ammonia (DNRA) becomes more and more important and seems to outcompete denitrification (Karlson et al., 2005).

\subsection{Uncertainties}

Our calculations are based on several uncertainties such as non-consideration of seasonal variations in denitrification, the question of whether our sediment-specific denitrification rates are representative or not, and finally, our choice of the $100 \mathrm{~m}$ depth line to separate between areas with oxygenated 
Table 6. Comparison of denitrification rates from Baltic Sea sediments from various studies.

\begin{tabular}{llll}
\hline Area & $\begin{array}{l}\text { Denitrification Rate } \\
{\left[\mu \mathrm{mol} \mathrm{N}, \mathrm{m}^{-2} \mathrm{~h}^{-1}\right]}\end{array}$ & Method & Reference \\
\hline Bothnian Bay & $5-6.7$ & Acetylene Block & (Stockenberg and Johnstone ,1997) \\
Bothnian Sea & $0-39.2$ & Acetylene Block & (Stockenberg and Johnstone, 1997) \\
Gulf of Finland & $4.2-27.1$ & Isotope Pairing & (Tuominen et al., 1998) \\
Gulf of Finland & $3.8-16.7$ & Isotope Pairing & (Hietanen and Kuparinen, 2008) \\
Northern Baltic Proper & $0.6-12.5$ & Isotope Pairing & (Tuominen et al., 1998) \\
Northern Baltic Proper & 49 & Flux studies & (Koop et al., 1990) \\
Southern Baltic and Baltic Proper & $0.5-28.7$ & Isotope Pairing & this study \\
\hline
\end{tabular}

waters above the sediment surface (denitrification in sediments) and anoxic waters above the sediment surface (no sedimentary denitrification).

As stated above, seasonality in the denitrification rate was observed in many studies. While some studies point out that there is a summer to fall maximum, the one by Kähler (1990) identifies spring as a short - one month - peak rate of denitrification, albeit measured with the acetylene block method at the time.

The rates used in this study were - with the exception of two stations - measured from late summer to late autumn. This seems to be a period where the denitrification rates in Baltic Sea sediments are high implying that our calculated $\mathrm{N}$-removal rates represent an upper estimate of N-removal for the Baltic Sea.

As pointed out above, the external supply of nitrate can enhance the denitrification rates (Kana et al, 1998). Although this was not important in our investigation $\left(\mathrm{D}_{n}>70 \%\right.$ at most stations), it must be assumed that there are areas in the Baltic Sea - presumably in close vicinity to river mouths - which are highly influenced by enhanced nitrate inputs and, thus, show high rates of $\mathrm{N}$-removal. Peak rates triggered by river runoff may occur predominantly in spring and may cause a shift to more $\mathrm{D}_{w}$ than we observed throughout the year. However, rates would have to be much higher if a significant overall yearly increase was to be expected: a doubling of the activity, as observed by Kähler (1990), during one month results in a yearly increase of $1 / 12$ or $\sim 8 \%$. Furthermore, fresh organic material undergoing sedimentation in a bloom situation may enhance denitrification rates over the level sustained by the more refractory carbon depicted in the surface sediment carbon contents. On the other hand, studies by Graf (1987) in the Baltic have shown that post-bloom redox conditions in sediments are often such that oxygen supply is no longer favorable and, therefore, strong C-supply may well reduce denitrification rates.

The second uncertainty regarding our N-removal calculations addresses the representativeness of our "sedimentspecific" rates of N-removal. Here, the rates measured in the sandy sediments (NS12, Gollwitz and Breitling) likely underestimate the true rate. The main reason for this is that the conditions during incubation of the isotope pairing experiments do not reflect the in-situ conditions. Permeable sediments are strongly influenced by pore-water advection which is completely interrupted during isotope pairing incubations. Gihring et al. (2010) reported higher denitrification rates for sands measured in intact sediment cores when the cores were permanently percolated with water compared to non-percolated cores. Gao et al. (2010) measured potential denitrification rates of $230 \mu \mathrm{mol} \mathrm{N} \mathrm{m}{ }^{-2} \mathrm{~h}^{-1}$ in sediments of a sand flat in the German Wadden Sea by means of isotope pairing measurements in intact sediment cores with simulated pore water advection. These rates are 50 times higher than our measured rate of $4.5 \mu \mathrm{mol} \mathrm{N} \mathrm{m} \mathrm{N}^{-2} \mathrm{~h}^{-1}$ in the sandy sediment. Furthermore, the study of Rao et al. (2008) showed that the formation of micro zones, in which denitrification takes place, leads to an underestimation of the denitrification rate measured by isotope pairing. However, we think that for the Baltic Sea the underestimation of the denitrification rate without simulating advective flow is lower than in the other areas (Wadden Sea, Gulf of Mexico) where the abovementioned studies were carried out. A difference is that the Baltic Sea is not or only marginally influenced by tides. This means that advective flow is only forced by currents and wind waves, which cause advective flow down to water depths of half a wavelength (Precht and Huettel, 2004). Furthermore, permeability $(\mathrm{k})$ in Baltic sediments is almost an order of magnitude lower than in other seas reflecting lower hydrodynamic energy. In the southern area of the Baltic Sea $\mathrm{k}$ is on the order of $2-8 \times 10^{-12} \mathrm{~m}^{-2}$ (Forster et al., 2003), reaching maximum values of $\sim 10^{-11} \mathrm{~m}^{-2}$. In contrast, the North Sea has $\mathrm{k}$ well in excess of $10^{-11} \mathrm{~m}^{-2}$ (Janssen et al., 2005) and Gihring et al. (2010) also report values well above $10^{-11}$ for the Gulf of Mexico.

For all other stations, our sediment-specific denitrification rates are in the range reported from other studies in the Baltic Sea (Koop et al., 1990; Tuominen et al., 1998; Hietanen and Kuparinen, 2008; Table 6). 
Furthermore, bioturbation is known to enhance denitrification (Pelegri et al., 1994; Gilbert et al., 2003). This issue has not been addressed, while theoretically, due to reduction of organism size with decreasing salinity, sediments further north-east in the Baltic would not bear the same potential for bioturbation-enhanced benthic denitrification as similar sediments located below saltier water in the west.

The third crucial point in our calculations from approaches $2-5$ is the use of the $100 \mathrm{~m}$-depth line to separate areas with benthic denitrification (areas $<100 \mathrm{~m}$ water depth) from anoxic areas without benthic denitrification (areas $\geq 100 \mathrm{~m}$ water depth) in the Central Baltic and the Gulf of Finland. The oxic area we calculated by using the $100 \mathrm{~m}$ depth line is $\sim 389000 \mathrm{~km}^{2}$ which is very close to the oxic area calculated from the DYNAS project for approach $1\left(\sim 392000 \mathrm{~km}^{2}\right)$. In the Central Baltic and the Gulf of Finland, usually permanent anoxic conditions prevail with the appearance of $\mathrm{H}_{2} \mathrm{~S}$ below water-depths $>100 \mathrm{~m}$ whereas in waters above $100 \mathrm{~m}$ depth anoxia occurs temporarily (Conley et al., 2009b). Furthermore, our calculated area shows good agreement with the anoxic areas presented in Hansson et al., 2009, and with the map showing the Baltic Sea anoxic areas of 2008 presented on the website of the Baltic Sea Portal (www.fimr.fi).

\subsection{Calculation of total N-removal from surface sediment $\mathrm{C}_{\text {org }}$ distribution}

With this approach, the $\mathrm{N}$ removal can only be reliably calculated for the western, southern, and central Baltic since for all other regions sufficient $\mathrm{C}_{\text {org }}$ data are not available. If we compare the calculated mean $\mathrm{N}$-removal rates from approach 4 where the remaining area outside the $\mathrm{C}_{\text {org }}$ distribution map is calculated with a $\mathrm{C}_{\text {org }}$ content of $0-1 \%(297 \mathrm{kt} \mathrm{N})$, we find an excellent agreement with the mean rates from approach 2 for the same area (total rate minus rate for Bothnian Sea, Bothnian Bay and Gulf of Finland: $290 \mathrm{kt} \mathrm{N}$ ). If the $\mathrm{N}$-removal from the remaining area is calculated with a $\mathrm{C}_{\text {org }}$ content of $1-2 \%$, the mean $\mathrm{N}$-removal rate increases by $\sim 75 \mathrm{ktN}$. A $\mathrm{C}_{\text {org }}$ content of $0-1 \%$ for the remaining areas seem reasonable to us since these are mainly coastal zones with a large proportion of sandy sediments and bedrock (AlHamdani and Reker, 2007).

\section{Conclusions}

With this study, we estimated - to our knowledge - the first $\mathrm{N}$-removal rates via sedimentary denitrification for an entire coastal sea. It could be shown that our way of combining one-point in situ measurements at different sediment stations with the application of sediment or $\mathrm{C}_{\text {org }}$ distribution maps is a powerful tool to estimate $\mathrm{N}$-removal via sedimentary denitrification and - if present - via Anammox for an ecosystem. For the Baltic Sea, it becomes obvious that the $\mathrm{N}$ removal via sedimentary denitrification is high, but, may not be high enough to balance all $\mathrm{N}$ inputs. The situation might exacerbate if the extension of the anoxic bottom areas continues and the $\mathrm{N}$-removal via sedimentary denitrification will be further reduced. The question that needs to be answered is whether the pronounced increase in water column denitrification that will occur, might be high enough to compensate the reduction of $\mathrm{N}$-removal via the sediments.

Acknowledgements. This work was supported by the German Science Foundation (DFG VO 487/10-1). We like to thank the Crews of the R/V Penck \& Poseidon, Iris Liskow, Frederike Korth, Nicola Wannicke, and Andreas Weiss for their help during the cruises, and Susanna Hietanen and Tage Daalsgaard for discussion and help in setting up the method. We also thank Detlev Schönborn for building the equipment, Thorsten Seifert and Bernd Bobertz for sharing maps and modeling results, and Thomas Leipe for additional $\mathrm{C}_{\text {org }}$ data.

Edited by: S. W. A. Naqvi

\section{References}

Al-Hamdani, Z. and Reker J.: Towards marine landscapes in the Baltic Sea. BALANCE interim report \#10, http://balance-eu. org/, ISBN: 978-87-7871-203-5, 2007.

Boynton, W. R., Garber, J. H., Summers, R., and Kemp, W. M.: Inputs, transformations, and transport of nitrogen and phosphorus in Chesapeake Bay and selected tributaries, Estuaries, 18, 285314, 1995.

Brettar, I. and Rheinheimer G.: Denitrification in the Central Baltic: evidence for $\mathrm{H}_{2} \mathrm{~S}$ oxidation as motor of denitrification at the oxic-anoxic interface, Mar. Ecol.-Prog. Series, 77, 157-169, 1991.

Cabrita, M. T. and Brotas. V.: Seasonal variation in denitrification and dissolved nitrogen fluxes in intertidal sediments of the Tagus estuary, Portugal, Mar. Ecol.-Prog. Series, 202, 51-65, 2000.

Childs, C. R., Rabalais, N. N., Turner, R. E., and Proctor, L. M.: Sediment denitrification in the Gulf of Mexico zone of hypoxia, Mar. Ecol.-Prog. Series, 240, 285-290, 2002.

Conley, D. J., Humborg, C., Rahm, L., Savchuk, O. P., and Wulff, F.: Hypoxia in the Baltic Sea and Basin-Scale Changes in Phosphorus Biogeochemistry, Environ. Sci. Technol., 36, 5315-5320, 2002.

Conley, D. J., Bjorck, S., Bonsdorff, E., Carstensen, J. Destouni, G, Gustafsson, B. G., Hietanen, S., Kortekaas, M., Kuosa, H., Meier, H. E. M., Muller-Karulis, B., Nordberg, K., Norkko, A., Nurnberg, G., Pitkanen, H., Rabalais, N. N., Rosenberg, R., Savchuk, O. P., Slomp, C. P., Voss, M., Wulff, F., and Zillen, L.: Hypoxia-Related Processes in the Baltic Sea, Environ. Sci. Technol., 43, 3412-3420, doi:10.1021/es802762a, 2009a.

Conley, D. J., Bonsdorff, E., Carstensen, J., Destouni, G., Gustafsson, B. G., Hansson, L. A., Rabalais, N. N., Voss, M., and Zillen, L.: Tackling Hypoxia in the Baltic Sea: Is Engineering a Solution? Environ. Sci. Technol., 43, 3407-3411, doi:10.1021/es8027633, 2009b

Dalsgaard T. and Thamdrup B.: Factors controlling anaerobic ammonium oxidation with nitrite in marine sediments, Appl. Environ. Microb., 68, 3802-3808, doi:10.1128/AEM.68.8.38023808.2002, 2002. 
Devol, A. H.: Denitrification including Anammox, in: Nitrogen in the Marine Environment, edited by: Capone, D., Bronk, D., Mulholland, M., and Carpenter, E., Academic Press, 263-301, 2008.

Diaz, R. J., and Rosenberg. R.: Spreading Dead Zones and Consequences for Marine Ecosystems, Science, 321, 926-929, doi:10.1126/science.1156401, 2008.

Dong, L. F., Thornton D. C. O., Nedwell D. B., and Underwood G. J. C.: Denitrification in sediments of the River Colne estuary, England, Mar. Ecol.-Prog. Series, 203, 109-122, 2000.

Eilola, K. and Stigebrandt A.: On the seasonal nitrogen dynamics of the Baltic proper biogeochemical reactor, J. Mar. Res., 57, 693-713, 1999.

Emeis, K. C., Struck, U., Leipe T., Pollehne F., Kunzendorf, H., and Christiansen, C.: Changes in the $\mathrm{C}, \mathrm{N}, \mathrm{P}$ burial rates in some Baltic Sea sediments over the last 150 years - relevance to $P$ regeneration rates and the phosphorus cycle, Mar. Geol., 167, 43-59, 2000.

Forster, S., Bobertz, B., and Bohling, B.: Permeability of Sands in the Coastal Areas of the Southern Baltic Sea: Mapping a Grainsize Related Sediment Property, Aquat. Geochem., 9, 171-190, 2003.

Galloway, J. N. Dentener, F. J., Capone, D. G., Boyer, E. W., Howarth, R. W., Seitzinger, S. P., Asner, G. P., Cleveland, C. C., Green, P. A., Holland, E. A., Karl, D. M., Michaels, A. F., Porter, J. H., Townsend, A. R., and Vorosmarty, C. J.: Nitrogen cycles: past, present, and future, Biogeochemistry, 70, 153-226, 2004.

Gao, H., Schreiber, F., Collins, G., Jensen, M. M., Kostka, J. E., Lavik, G., de Beer, D., Zhou, H., and Kuypers, M. M. M.: Aerobic denitrification in permeable Wadden Sea sediments, The ISME Journal 4, 417-426, 2010.

Gihring, T. M., Canion, A., Riggs, A., Huettel, M., and Kostka, J. E.: Denitrification in shallow, sublittoral Gulf of Mexico permeable sediments, Limnol. Oceanogr., 55, 43-54, 2010

Gilbert, F., Aller, R. C., and Hulth, S.: The influence of macrofaunal burrow spacing and diffusive scaling on sedimentary nitrification and denitrification: An experimental simulation and model approach, J. Mar. Res., 61, 101-125, 2003.

Graf G.: Benthic response to the annual sedimentation pattern, in: Lecture notes on coastal and estuarine studies Vol. 13. Seawatersediment interactions in coastal waters, an interdisciplinary approach, edite by: Rumohr, J., Walger, E., and Zeitschel, B., Springer-Verlag, New York, 84-92, 1987.

Hagy J. D., Boynton, W. R., Keefe, C. W., and Wood, K. V.: Hypoxia in Chesapeake Bay, 1950-2001: Long-term Change in Relation to Nutrient Loading and River Flow. Estuaries, 27, 634658, 2004.

Hansson, M., Axe, P., and Andersson L.: Extent of anoxia and hypoxia in the Baltic Sea, 1960-2009, SMHI, Dnr: Mo 2009-214, Norrkping, 57pp., 2009.

HELCOM: Baltic Sea Environment Proceedings: Third periodic assessment of the state of the marine environment of the Baltic Sea, 1989-93, Balt. Sea Environ. Proc. Helsinki Commission, 64B, 252, 1996.

Hietanen, S. and Kuparinen. J.: Seasonal and short-term variation in denitrification and anammox at a coastal station on the Gulf of Finland, Baltic Sea, Hydrobiologia 596, 67-77, doi:10.1007/s10750-007-9058-5, 2008.

Hulth, S., Aller, C. A., Canfield, D. E., Dalsgaard, T., En- gström, P., Gilbert, F., Sundbäck K., and Thamdrup, B. :Nitrogen removal in marine environments: recent findings and future research challenges, Mar. Chem., 94, 125-145, doi:10.1016/j.marchem.2004.07.013, 2005.

Janssen, F., Huettel, M., and Witte, U.: Pore-water advection and solute fluxes in permeable marine sediments (II): Benthic respiration at three sandy sites with different permeabilities (German Bight, North Sea), Limnol. Oceanogr. 50, 779-792, 2005.

Jones, M. N.: Nitrate reduction by shaking with cadmium: Alternative to cadmium columns. Water Res., 18, 643-646, 1984.

Kähler, P.: Denitrification in coastal marine sediments (in German). Berichte aus dem Institut fuer Meereskunde an der CAU Kiel, 199, 104 pp., 1990.

Kana, T. M., Sullivan, M. B., Cornwell J. C., and Groszkowski, K.: Denitrification in estuarine sediments determined by membrane inlet mass spectrometry, Limnol. Oceanogr., 43, 334-339, 1998.

Karlson, K., Hulth, S., Ringdahl, K., and Rosenberg, R.: Experimental recolonisation of Baltic Sea reduced sediments: survival of benthic macrofauna and effects on nutrient cycling, Mar. Ecol.-Prog. Series, 294, 35-49, 2005.

Koop, K., Boynton, W. R., Wulff, F., and Carman, R.: Sedimentwater oxygen and nutrient exchanges along a depth gradient in the Baltic Sea, Mar. Ecol.-Prog. Series, 63, 65-77, 1990.

Kuypers M. M. M., Lavik, G., Woebken, D., Schmid, M., Fuchs, B. M., Amann, R., Jørgensen B. B., and Jetten, M. S. M.: Massive nitrogen loss from the Benguela upwelling system through anaerobic ammonium oxidation, PNAS, 102, 64786483, doi:10.1073/pnas.0502088102, 2005

Kuypers M. M. M., Sliekers, A. O., Lavik, G., Schmid, M., Jorgensen, B. B., Kuenen, J. G., Sinninghe Damsté J. S., Strous M., and Jetten, M. S. M.: Anaerobic ammonium oxidation by anammox bacteria in the Black Sea, Nature, 422, 608-611, doi:10.1038/nature01472, 2003.

Lam P., Lavik, G., Jensen, M. M., Vossenberg, J. v. d., Schmid, M., Woebken, D., Gutierrez, D., Amann, R., Jetten M. S. M., and Kuypers, M. M. M.: Revising the nitrogen cycle in the Peruvian oxygen minimum zone, PNAS, 106, 4752-4757, doi:10.1073/pnas.0812444106, 2009.

Laursen, A. E. and Seitzinger, S. P.: Measurement of denitrification in rivers: an integrated, whole reach approach, Hydrobiologia, 485, 67-81, 2002.

Leipe, T., Tauber, F., Vallius, H., Virtasalo, J., Ucinowicz, S., Kowalski, N., Hille, S., Lindgren, S., and Myllyvirta, T.: Particulate organic carbon (POC) in surface sediments of the Baltic Sea, accepted, Geo. Mar. Lett., 2010.

Lohse, L., Kloosterhuis, H. T., Vanraaphorst, W., and Helder, W.: Denitrification rates as measured by the isotope pairing method and by the acetylene inhibition technique in continental shelf sediments of the North Sea, Mar. Ecol.-Prog. Series, 132, 169179, 1996.

Mee, L. D., Friedrich, J., and Gomoiu, M.-T.: Restoring the Black Sea in times of uncertainty, Oceanography, 18, 32-43, 2005.

Mee L. D.: Reviving dead zones, Sci. Am., 295, 54-61, 2006.

Nielsen, L. P.: Denitrification in sediment determined from nitrogen isotope pairing, FEMS Microbiol. Lett., 86, 357-362, 1992.

Nowicki, B. L., Kelly, J. R., Requintina, E., and Keuren, D. V.: Nitrogen losses through sediment denitrification in Boston Harbor and Massachusetts Bay, Estuaries, 20, 626-639, 1997.

Pelegri, S., Nielsen, L. P., and Blackburn, T. H.: Denitrification in 
estuarine sediment stimulated by the irrigation activity of the amphipod Corophium volutator, Mar. Ecol.-Prog. Series, 105, 285290, 1994.

Pettijohn, F. J., Potter, P. E., and Siever, R.: Sand and Sandstone, Berlin, Springer Verlag, 618 pp., 1973

Piña-Ochoa, E. and Álvarez-Cobelas, M.: Denitrification in aquatic environments: a cross-system analysis, Biogeochemistry, 81, 111-130, doi:10.1007/s10533-006-9033-7, 2006.

Precht, E. and Huettel, M.: Rapid wave driven advective pore water exchange in a permeable coastal sediment, J. Sea Res., 51, 93107, 2004.

Preisendorfer, R. W.: Principle Component Analysis in Meteorology and Oceanography, Elsevier, Amsterdam, 1988.

Rao, A. M. F., McCarthy, M. J., Gardner, W. S., and Jahnke, R. A.: Respiration and denitrification in permeable continental shelf deposits on the South Atlantic Bight: N2: Ar and isotope pairing measurements in sediment column experiments, Cont. Shelf Res. 28, 602-613, 2008.

Risgaard-Petersen, N., Nielsen, L. P., Rysgaard, S., Dalsgaard, T., and Meyer, R. L.: Application of the isotope pairing technique in sediments where anammox and denitrification coexist, Limnol. Oceanogr.-Meth., 1, 63-73, 2003.

Sakamaki, T. and Nishimura. O.: Physical control of sediment carbon content in an estuarine tidal flat system (Nanakita River, Japan): A mechanistic case study, Estuar. Coast. Shelf S., 73, 781-791, doi:10.1016/j.ecss.2007.03.019, 2007.

Savchuk, O. P.: Resolving the Baltic Sea into seven subbasins: $\mathrm{N}$ and P budgets for 1991-1999, J. Marine Syst., 56, 1-15, doi:10.1016/j.jmarsys.2004.08.005, 2005.

Schinke, H. and Matthäus, W.: On the causes of major Baltic inflows - an analysis of long-term series, Cont. Shelf. Res., 18, 67-97, 1998.

Seifert, T., Tauber, F., and Kayser, B.: A high resolution spherical grid topography of the Baltic Sea - 2nd edition (abstract), Baltic Sea Science Congress 2001: past, present and future - a joint venture; abstract volume, Stockholm: Stockholm Marine Research Centre, Stockholm Univ., 298, 2001.

Seitzinger, S. P.: Denitrification in freshwater and coastal marine ecosystems: Ecological and geochemical significance, Limnol. Oceanogr., 33, 702-724, 1988.

Seitzinger, S. P., Nielsen, L. P., Caffrey, J., and Christensen, P. B.: Denitrification measurements in aquatic sediments - A comparison of 3 methods, Biogeochemistry, 23, 147-167, 1993.
Seitzinger, S. P., Nixon, S. W., and Pilson, M. E. Q.: Denitrification and nitrous-oxide production in a coastal marine ecosystem, Limnol. Oceanogr., 29, 73-83, 1984.

Seitzinger, S. P., Harrison, J. A., Böhlke, J. K., Bouwman, A. F., Lowrance, R., Peterson, B., Tobias C., and Drecht G. V: Denitrification across landscapes and waterscapes: A synthesis, Ecol. Appl., 16, 2064-2090, 2006.

Shaffer, G. and Rönner. U.: Denitrification in the Baltic Proper deep-water, Deep-Sea Res., 31, 197-220, 1984.

Steingruber, S. M., Friedrich, J., Gachter, R., and Wehrli, B.: Measurement of denitrification in sediments with the N-15 isotope pairing technique, Appl. Environ. Microb., 67, 3771-3778, 2001.

Stockenberg, A. and Johnstone, R. W.: Benthic denitrification in the Gulf of Bothnia, Estuar. Coast. Shelf S., 45, 835-843, 1997.

Sundbäck, K., Miles, A., and Goransson, E.: Nitrogen fluxes, denitrification and the role of microphytobenthos in microtidal shallow-water sediments: an annual study, Mar. Ecol.-Prog. Series, 200, 59-76, 2000.

Trimmer, M. and Nicholls, J. C.: Production of nitrogen gas via anammox and denitrification in intact sediment cores along a continental shelf to slope transect in the North Atlantic, Limnol. Oceanogr., 54, 577-589, 2009.

Tuominen, L., Heinanen, A., Kuparinen, J., and Nielsen, L. P.: Spatial and temporal variability of denitrification in the sediments of the northern Baltic Proper, Mar. Ecol.-Prog. Series, 172, 13-24, 1998.

Turner, E. R. and Rabalais, N. N.: Coastal eutrophication near the Mississipi river delta., Nature, 368, 619-621, 1994.

Voss, M., Emeis, K. C., Hille, S., Neumann, T., and Dippner, J. W.: Nitrogen cycle of the Baltic Sea from an isotopic perspective, Global Biogeochem. Cy., 19, doi:10.1029/2004GB002338, 2005.

Wasmund, N., Voss, M., and Lochte, K.: Annual nitrogen fixation patterns in the Baltic Proper, Mar. Ecol.-Prog. Series, 214, 1-14, 2001.

Winkler, L. W.: Die Bestimmung des im Wasser gelösten Sauerstoffes, Berichte der deutschen chemischen Gesellschaft, 21, 2843-2854, 1888.

Wulff, F., Humborg, C., Medina, M. R., Mörth, C.-M., Savchuk, O., and Sokolov, A.: Revision of the country allocation of nutrient reductions in the Baltic Sea Action Plan Section A: Hydrological adjusted riverine loads and atmospheric loads from different countries averaged for 2000-2006, 1-47, Baltic Nest Institute, Stockholm Resilience Center, Stockholm, 2009. 